Relations industrielles

Industrial Relations

\title{
Alexander Lockhart, School Teaching in Canada
}

\section{John Harp}

Volume 47, numéro 1, 1992

URI : https://id.erudit.org/iderudit/050758ar

DOI : https://doi.org/10.7202/050758ar

Aller au sommaire du numéro

Éditeur(s)

Département des relations industrielles de l'Université Laval

ISSN

0034-379X (imprimé)

1703-8138 (numérique)

Découvrir la revue

Citer ce compte rendu

Harp, J. (1992). Compte rendu de [Alexander Lockhart, School Teaching in Canada]. Relations industrielles / Industrial Relations, 47(1), 176-178.

https://doi.org/10.7202/050758ar

Tous droits réservés (C) Département des relations industrielles de l'Université Laval, 1992
Ce document est protégé par la loi sur le droit d'auteur. L'utilisation des services d'Érudit (y compris la reproduction) est assujettie à sa politique d'utilisation que vous pouvez consulter en ligne.

https://apropos.erudit.org/fr/usagers/politique-dutilisation/ 
Enfin, le dernier chapitre tente d'amorcer une réflexion afin d'identifier des pistes de solution alternatives à la stratégie de précarisation des emplois. Encore une fois, l'auteure présente de façon simple et claire les théories économiques (malheureusement, encore une fois, sans références systématiques) qui peuvent servir à identifier les stratégies possibles. Ici sont amenées les thèses sur la segmentation des marchés du travail qui montrent les risques d'un éclatement du marché du travail entre les «bons» et les «mauvais» emplois. En présentant les modèles traditionnels de gestion de main-d'oeuvre encore dominants dans les grandes entreprises (le système d'emploi industriel et le système d'emploi salarié), l'auteure met le doigt sur différentes pratiques (telles la règle de l'ancienneté ou encore la règle de la sécurité d'emploi) qui viennent en porte-à-faux à la recherche de flexibilité des entreprises. Face à cela, l'auteure suggère, en conclusion, une stratégie axée sur la formation professionnelle et la mobilité des personnes en emploi. Ce dernier chapitre aurait pu mieux cibler, à notre avis, les pistes de solutions possibles s'il avait clairement identifié les propositions amenées par les différents groupes sociaux actifs sur la question de l'emploi dans la société québécoise actuelle.

Notre principale critique de ce livre est d'ailleurs d'avoir présenté les entreprises comme le seul moteur des stratégies d'emploi; les syndicats et les autres groupes sociaux, comme le aForum pour l'emploi», sont absolument absents du modèle d'analyse. Ceci n'est pas sans laisser un malaise quand on sait que se dessine au Québec un modèle original de concertation sur les questions reliées à l'emploi que commencent à envier les autres provinces canadiennes. Aussi doit-on considérer ce livre pour ce qu'il est: un livre qui fait état de façon simple et condensée des principales théories économiques liées à la question de l'emploi; un livre qui expose bien les statistiques récentes sur les nouvelles formes d'emploi; un livre qui, par sa présentation bien articulée des théories de l'emploi, peut provoquer une réflexion stimulante; un livre cependant où les stratégies des acteurs sociaux sont absentes et où donc l'analyse concrète de l'évolution du marché de l'emploi au Québec laisse à désirer. Malgré cette lacune, c'est un livre à lire pour qui veut comprendre les grandes tendances de l'emploi.

Colette Bernier

Université Laval

School Teaching in Canada, by Alexander Lockhart, Toronto, University of Toronto Press, 1991, 175 p., ISBN 0-8020-2748-2 (cloth) and ISBN 08020-67883 (paper)

Alexander Lockhart's informative and comprehensive survey of Canadian elementary and secondary school teachers is one of several studies of the profession in Canada initiated by the Analytical Studies Branch of Statistics Canada under the direction of Paul Reed. Among the topics discussed in this work are the characteristics of today's teachers, the conditions under which they work, their professional associations, career patterns in teaching, the political environment, current pedagogy, and the public interest. The resulting work goes far beyond the usual narrowly conceived analysis or profile of a single 
occupation. Indeed Lockhart sets broad goals for the study, namely "To situate teachers within the broader socio-political economic context", and thereby understand changes in the occupation, as well as "To produce a holistic picture without distortion of regional variations and successfully blend quantitative and qualitative analyses." He is highly successful in achieving both objectives, and in the process offers an insightful and carefully researched interpretation of data from a broad range of studies within the sociology of education.

With regard to the socio-historical context and the social characteristics and institutional dynamics that "define teachers occupational realities", Lockhart touches upon demographic and economic changes since World War II, organizational dimensions within which recruitment, training, practice and rewarding of public school teachers takes place, and finally how these dimensions have affected teachers relative to other groups. His discussion of teachers' response to a surplus market involving the creation of a two tier membership structure should be of considerable interest to other occupations also experiencing changes in their labour process, i.e., university teachers.

Teachers' characteristics or the changing profile of the occupation has received wide attention in the literature for several decades, but more often the studies are limited in scope and restrictive in terms of the populations sampled. It is here that Lockhart manages to move beyond the limitations of individual studies to synthesize a social portrait of the changing characteristics of teaching. For example, changes in the gendered composition of the labour force are explored over time. He reports that "... close examination of the gender distribution within the hierarchical structure of the public career system reveals not only retention of traditional patriarchal social attributes with respect to who 'nurtures' and who 'commands' but also as one federal government affirmative action report underscores (Statistics Canada, 1980. Comparative Analysis of Male/Female Staff in the Ontario Educational System 1972 to 1979. Ottawa: Affirmative Action Unit, Ministry of Supply and Services) a strong resistance to the now widely accepted public and private sector equal opportunity promotion practices" (p. 31). The previous statement is of special relevance when considered in the light of the Ontario Ministry's recent Memorandum III with the expressed goal that by the year 2000 , fifty percent of all administrative positions in the public system are to be filled by women. It is important also to note that Lockhart goes on to state that "... deeply entrenched institutional norms and practices, not self deprecating attitudes on the part of female teachers, are responsible for the extraordinarily low proportion of women teachers who occupy administrative positions through to at least the mid 1980's" (p. 32).

Turning to value orientations and questions regarding the authoritarian character of teachers' pedagogical practices, Lockhart cleverly resorts to special runs of data from the Carleton University Class Structure Project. This strategy allows him to make comparisons of teachers with "hourly" and "managerial and professional" groups. He reports, "The majority of teachers seem to occupy the ideological middle ground" (p. 53). The large "no strong opinion majority" further leads him to conclude that institutional factors are likely to be instrumental in orienting teachers toward the "bureaucratically favoured instrumental-authoritarian pattern" (p. 53). 
Any comprehensive analysis of occupations must move beyond the design of work to consider the conditions and experience of work, and this Lockhart does with considerable aplomb. He carefully documents historical changes such as the decline in the market for highly qualified manpower, and the recently imposed higher recruitment standards as factors which may increase teachers' occupational committment. Again a special run of data from the Carleton University Class Structure Project allows comparisons of teachers with hourly wage workers and managerial professional groups, and shows that teachers have both the highest median income and the highest proportion of members at the median income level (p. 68).

The pervasive issue of autonomy and control throughout the literature on professions becomes a special case for teachers. Lockhart concludes that "... teachers do not appear to be exceptionally committed to full professional autonomy" (p. 75). However, he also reports certain contradictions that inhere in the work culture. Whereas teachers "... require and are afforded the freedom to be innovative in the way they approach their classroom work, they are not given commensurate freedom over curricular content and scheduling" (p. 81).

Although teachers' associations beginning in the 1960's moved from a "genteel professionalism to a more militant unionism", bread and buter issues of salary tended to dominate union agendas. Furthermore the point is well taken that strike activity by public service employees is often felt more by clients than employers and can result in damage to the "special trust between worker and community". The ongoing politicization of teachers associations shows evidence of being both confrontational and coalitional. However teachers' efforts to develop a more professionally responsible work environment are constantly encountering a crisis of authority both within and beyond the classroom.

Finally, the tension between collegial versus hierarchical control over the organization and delivery of a knowledge based service is certainly a pervasive issue, as Lockhart points out. However, as this study and others have shown there are some serious impediments in the way of teachers taking more responsibility in shaping the goals and conditions of schooling. Indeed given the press of everyday activities, teachers often have little for critical reflection let alone challenge.

Lockhart has provided all interested stakeholders in Canada's public educational system with an important account of the major issues affecting the teaching profession and education. It should be required reading for them all.

John HARP

Carleton University

The Three Worlds of Welfare Capitalism, by Gösta Esping-Andersen, Princeton, N.J., Princeton University Press, 1990, XI+248 p., ISBN 0-69102857-5

The study done by the author questions the validity of the convergence theory on the basis of empirical test applied to the countries that are different in 